\title{
KAJIAN ASIMETRI INFORMASI DALAM PENENTUAN ALOKASI ANGGARAN
}

\section{Achmad Fauzan Sirat}

Email: af.sirat05@gmail.com

\section{Intisari}

Asimetri informasi adalah suatu kondisi dimana satu pihak mempunyai informasi yang lebih daripada pihak lain sehingga salah satu pihak akan dapat mengambil manfaat dari pihak yang lain. Dalam alokasi anggaran hal inipun terjadi yang berpotensi menimbulkan overallocated ataupun underallocated dari anggaran. Menteri Keuangan sebagai wakil pemerintah dalam menjaga stabilitas fiskal berkepentingan agar alokasi anggaran sesuai dengan yang dibutuhkan (anggaran ideal). Kondisi ini dalam kenyataannya bisa tidak tercapai apabila terdapat asimetri informasi dalam dalam penentuan alokasi anggaran.

Kajian ini bertujuan memberikan gambaran fungsi standar biaya dalam rangka mengatasi kondisi asimetri informasi melalui proses signalling dan screening. Kajian ini mengungkapkan bahwa standar biaya masukan merupakan bagian dari proses signaling sedangkan standar biaya keluaran termasuk bagian dari proses screening. Namun demikian kajian ini secara khusus menekankan pada proses screening. Simulasi lebih lanjut mengenai proses screening tersebut dilakukan melalui metode statistik deskriptif terkait dengan kecenderungan nilai tengah atas data yang ada.

Dalam simulasi tersebut, rata-rata dapat menjadi upaya untuk mencari indikasi kecenderungan umum dalam memproduksi suatu output. Selain itu, pengelompokan output dalam jenis tertentu dapat menjadi upaya untuk mencari indikasi kecenderungan umum dalam memproduksi suatu output. Kualitas penentuan benchmark bergantung pada kualitas data yang dimiliki. Dengan asumsi angka MTEF sudah benar, alokasi dana untuk tahun yang direncanakan adalah cost per unit dari output hasil dari proses screening dikalikan dengan kuantitas output yang akan dilaksanakan. Atau dengan kata lain: Alokasi $=P \times Q$, dimana $P=$ Ouput-Cost per unit dan $Q=a n g k a$ output yang akan dihasilkan. Hal ini juga dapat menjadi solusi atas keakuratan alokasi untuk mengurangi budgetary slack, serta menjadi media untuk meninggalkan fokus detail dibawah output.

Kata kunci: informasi asimetri, standar biaya, alokasi anggaran

\section{PENDAHULUAN}

\subsection{Latar Belakang}

Proses penganggaran pada
dasarnya merupakan media untuk
menentukan pelayanan apa saja yang akan pemerintah berikan dan bagaimana pelayan tersebut akan dibiayai. Hal tersebut dapat pula digunakan untuk membantu merumuskan bagaimana suatu layanan tersebut dapat diberikan. Pertanyaan mendasar dalam proses pengalokasian anggaran adalah atas dasar apa pemerintah mengalokasikan dananya pada kegiatan A daripada kegiatan B. Hal tersebut lebih dikenal dengan kata penentuan prioritas saat dihadapkan suatu pilihan yang mutually exclussive. Sejalan dengan statement diawal, pertanyaanpertanyaan selanjutnya akan menuju pada 
bagaimana kegiatan A akan dibiayai, berapa besar biayanya serta bagaimana kegiatan A akan dilakukan.

Dengan kata lain, proses penganggaran harus dapat menjamin pengalokasikan sumberdaya terbatas pada kegiatan-kegiatan ekonomi yang dipilih sebagai prioritas. Secara teoritis prioritasprioritas tersebut selayaknya dilakokasikan sumberdaya yang sesuai dengan kebutuhan, mengingat ada opportunity cost yang dipertaruhkan jika variasi atas alokasi terlalu besar. Namun pada kenyataannya sering kali pengalokasian sumberdaya tersebut jauh dari kesesuaian dengan kebutuhan. Hal ini berakibat pada suatu kondisi overallocated maupun underallocated atas suatu kegiatan.

Kondisi misalokasi dalam konteks tersebut pada akhirnya akan mempunyai konsekuensi atas kinerja pencapaian output bahkan outcome. Misalkan kegiatan ekonomi yang memerlukan sumber daya yang besar mendapatkan alokasi lebih kecil dari kebutuhan dapat berakibat hasil tidak maksimal atau bahkan kegiatan tidak dapat dilaksanakan dengan baik.

\subsection{Identifikasi Masalah}

Pengalokasian sumberdaya sendiri mempunyai masalah yang sama berat dengan penentuan prioritas. Secara sadar maupun tidak, dalam pengalokasian sumber daya dimaksud penelaah mengalami suatu keadaan yang dalam ilmu ekonomi dikenal sebagai asimetri informasi. Dimana hasil akhir dari kondisi tersebut adalah misalokasi sumberdaya yang terbatas pada kegiatan-kegiatan yang dipilih oleh pemerintah untuk dilaksanakan.

\subsection{Tujuan}

Tulisan ini akan mengulas lebih lanjut mengenai kondisi asimetri informasi secara umum untuk mendapatkan pengetahuan tentang bagaimana mengatasi kondisi tersebut. Selanjutnya pengetahuan tersebut menjadi dasar atas kemungkinan penerapan atas pengetahuan tersebut dalam pengalokasian anggaran sehingga dapat menjadi alat yang efektif dalam mengurangi ketidakseimbangan pengetahuan sebagai akibat dari asimetri informasi.

\section{METODOLOGI PENELITIAN}

Kajian ini dibuat dengan menggunakan pendekatan metode statistik deskriptif guna mendukung simulasi kualitatif.

\section{KAJIAN PUSTAKA}

\subsection{Sekilas tentang asimetri informasi}

Asimetri informasi didefinisikan sebagai suatu kondisi dimana satu pihak mempunyai informasi yang lebih daripada pihak lain. Sebagai akibat, salah satu pihak akan dapat mengambil manfaat dari pihak yang lain dari kepemilikan informasi tersebut. Sebagaimana Stigler (1961) menyatakan dalam pembukaan tulisannya: The Economic of Information: "Information is avaluable resource: Knowledge is power". Contoh Asimetri Informasi yang relevan dengan topik tulisan ini adalah adverse selection, yakni suatu kondisi (karena keterbatasan informasi yang dimiliki) dimana atas barang (proposal) yang ditawarkan tidak sesuai antara harga dan qualitasnya. 
Terdapat dua hal menurut literatur yang sama yang dapat dijadikan solusi terhadap permasalahan asimetri informasi tersebut, yakni signalling dan screening. Kedua konsep tersebut akan dijelaskan sebagai berikut:

\section{a. Signalling}

Konsep adverse selection sebagaimana disimulasikan oleh Arkelof (1970) pada pasar mobil bekas "The Market for Lemons" merupakan salah satu contoh implikasi konsep tersebut dalam kehidupan sehari-hari. Dalam kesimpulannya, adanya adverse selection membuat barang bagus dengan harga yang rasional dipaksa keluar dari pasar (it drives apple out of the market) sehingga pasar hanya berisi barang tidak berkualitas (lemons) dengan harga yang tidak rasional. Selanjutnya ada dua solusi yang ditawarkan untuk mengatasi kondisi tersebut, yakni signaling, dan screening.

Signaling merupakan upaya mengatasi hal tersebut melalui signalsignal yang dapat membuktikan kualitasnya (dalam saat bersamaan pihak lainnya dapat memperkirakan harga atas kualitas yang diberikan). Contoh sinyalsinyal tersebut adalah garansi untuk pasar mobil bekas, dan ijazah untuk pasar tenaga kerja. Adanya sinyal tersebut seolah-olah memberikan informasi atas kualitas tertentu dari suatu barang sehingga pihak terkait akan bersedia membayar dengan harga yang rational untuk mendapatkan manfaat ekonomis barang tersebut. Prinsip dasar dari signaling adalah pihak yang berkepentingan tidak melakukan pencarian informasi, namun memanfaatkan informasi yang dibuat oleh pihak lain sebagai jaminan atas suatu kondisi tertentu.

\section{b. Screening}

Screening merupakan upaya pihak yang berkepentingan untuk melakukan pencarian informasi. Contoh proses screening adalah test drive dan cek fisik untuk pasar mobil bekas, serta test masuk dan masa percobaan untuk pasar tenaga kerja. Screening dilakukan untuk mendapatkan pilihan yang terbaik atas kombinasi harga dan kualitas atas barang yang ditawarkan.

Keputusan menggunakan satu dari dua pendekatan atau kombinasi keduanya harus mempertimbangkan biaya-manfaat dari pilihan tersebut. Setiap pilihan membawa konsekuensi biaya dalam pelaksanaannya. Dalam beberapa hal, signal yang dijadikan referensi tidak sepenuhnya sesuai dengan kebutuhan yang spesifik, seperti tidak semua orang berijasah mempunyai kemampuan yang sama dalam berkomunikasi. Paralel dengan itu, proses screening terkadang membutuhkan waktu dan biaya yang tidak sedikit.

\subsection{Asimetri Informasi dan Alokasi Anggaran}

Dalam alokasi anggaran, sadar maupun tidak asimetri informasi juga terjadi. Dapat dicontohkan tiga kondisi dalam penganggaran dimana informasi tidak benar-benar tersaji sama antara kedua belah pihak. Misalnya, penentuan rangking prioritas, penetapan level kinerja/kualitas dari suatu output yang akan diproduksi, serta perhitungan biaya yang dibutuhkan untuk memproduksi output tersebut. Terkait dengan biaya, pertanyaan mendasar dari penilaian dana suatu 
kegiatan adalah apakah biaya yang diusulkan sudah sebesar kebutuhannya.

Pada saat diskusi atas kelayakan suatu proposal (dalam kaitannya dengan biaya), pengusul secara alamiah memiliki informasi yang lebih daripada reviewernya. Hal ini didukung dengan rasionalitas yang tertanam dalam diri seorang reviewer yang selalu mencari cara untuk mengurangi dana yang diusulkan, serta kekurangmampuan reviewer untuk mencari informasi atas kegiatan sepadan. Hasilnya, usulan dana atas kegiatan tersebut tidak menggambarkan kebutuhan dana yang sesungguhnya, suatu kondisi yang dikenal sebagai overallocated atau underallocated.

Akankah kondisi ini dapat terselesaikan dengan sendirinya? Tentu bisa. Apabila pengusul dan reviewernya dapat mengurangi ego masing-masing dalam diskusi atas proposal yang diajukan. Namun, hal itu merupakan kondisi yang patut diduga jauh panggang dari api mengingat masing-masing pihak mempunyai insentif untuk tidak melakukannya.

Bagi Reviewer, proposal anggaran diasumsikan selalu diajukan dengan terlalu banyak penggelembungan. Sehingga prilaku yang ditunjukkan didominasi oleh keinginan untuk mengurangi jumlah dari alokasi yang dibutuhkan. Belum lagi apabila kinerja reviewer didasarkan atas berapa banyak pemotongan yang dilalukan (savings).

Mengantisipasi hal tersebut, pengusul selalu berpikir bahwa proposalnya pasti akan dipotong lebih kecil dari kebutuhan riel sehingga pengusul mempunyai insentif untuk menggelembungkan usulannya agar saat dilakukan rasionalisasi usulan, dana yang diterima akan mendekati kebutuhannya.

Selain itu dalam beberapa literatur akuntansi managemen disebutkan bahwa asimetri informasi juga disebabkan oleh perilaku para manager yang tergoda melakukan distorsi atas informasi untuk kepentingannya sendiri. Perilaku ini dikenal sebagai slack behavior ${ }^{1}$. Slack timbul dari kecenderungan suatu organisasi atau individu untuk tidak mengoptimalkan penggunaaan sumberdaya yang ada.

Insentif yang didapat para manager atas slack dapat berupa pencapaian target yang mudah dilakukan karena kapasitas yang dianggarkan sebenarnya masih dibawah optimal (underutilesed). Penentuan target yang mudah akan berujung pada penilaian kinerja yang sangat baik.

Kondisi ini sebenarnya tidak sesuai dengan kenyataan bahwa alokasi yang optimal harus dilakukan dengan konstrain sumber daya terbatas guna memenuhi semua ekspektasi stakeholder atas layanan. Dalam hal ini, kondisi overallocated berkontribusi meniadakan kegiatan lain, sedangkan kondisi underallocated berkontribusi tidak tercapainya outcome yang direncanakan.

Jika kondisi tersebut benar adanya, maka perlu pendekatan komprehensif untuk menyelesaikannya. Solusi sesuai dengan konsepsi signaling dan screeningpun menjadi relevan dengan

\footnotetext{
${ }^{1}$ Belkaoui, AR., Behavioral Management Accounting, Quorom Books, 2002, p.225.
} 
pengalokasian anggaran yang menjadi topik tulisan ini.

\section{PEMBAHASAN}

\subsection{Standar Biaya Sebagai Salah Satu Langkah Mengurangi Asimetri Informasi}

Menteri Keuangan sebagai wakil pemerintah dalam menjaga stabilitas fiskal berkepentingan agar alokasi anggaran sesuai dengan kebutuhan. Sesuai kebutuhan berarti alokasi tidak terlalu besar (overallocated) ataupun alokasi terlalu rendah (underallocated). Alokasi yang sesuai dengan kebutuhan akan membuat kondisi yang dikenal dengan allocative efficiency ${ }^{2}$ terjadi.

Allocative efficiency menjadi penting karena sejatinya pelayanan yang diharapkan oleh masyarakat kepada pemerintah adalah sangat banyak, dimana sumber daya pemerintah untuk memenuhi ekspektasi masyarakat tersebut terbatas. Sehingga alokasi yang tepat serta akurat sangat dibutuhkan untuk memenuhi semua pelayanan yang diharapkan kepada masyarakat.

Kondisi di atas dalam kenyataannya bisa tidak tercapai apabila terdapat asimetri informasi dalam dalam penentuan alokasi tersebut. Bahasan berikut menguraikan bagaimana kebijakan standar biaya -sebagai salah satu pilar penganggaran berbasis kinerja- dapat menjadi salah satu langkah untuk

\footnotetext{
${ }^{2}$ Allocative efficiency merupakan suatu term untuk menggambarkan kondisi dimana Marginal Cost = Marginal Benefit. Terkait dengan topik tulisan ini allocative efficiency digunakan untuk menggambarkan kondisi dimana tambahan biaya yang dikeluarkan/dialokasikan = tambahan output yang dihasilkan.
}

mengurai masalah asimetri dimaksud mengacu konsepsi signaling dan screening.

\subsection{Signaling dalam Penganggaran}

Signaling pada prinsipnya telah diakomodasi dengan kebijakan standar biaya Masukan (SBM). Penetapan kebijakan SBM atas beberapa item input berupaya memberikan assurance bahwa biaya (cost) atas suatu item merupakan harga paling rasional $^{3}$ yang tersedia di pasar.

SBM ditetapkan oleh Menteri Keuangan setelah diadakan survey atas harga yang terdaftar dengan norma perhitungan tertentu. SBM selanjutnya menjadi dasar Kementerian Negara/Lembaga dalam menyusun asumsi perhitungan biaya untuk suatu proposal output/kegiatan/program.

Saat kebijakan tersebut menjadi pedoman bagi pengusul selayaknyalah item cost per unit tersebut tidak menjadi area of dispute dan locus of interest dari para Reviewer. Hal ini dimungkinkan mengingat SBM, pada dasarnya, merupakan informasi pasar yang dihimpun sendiri oleh pihak Reviewer (Kementerian Keuangan) dengan mempertimbangkan variasi harga yang ada.

Sedangkan untuk item yang tidak tercakup dalam SBM yang ditetapkan, Surat Pernyataan Tanggung Jawab Mutlak (SPTJM) atau disclaimer statement atas tanggung jawab dari apa yang tercantum

\footnotetext{
3 Penggunaan kata 'harga yang paling rasional' tidak berarti tidak ada markup dalam praktiknya mengingat standar biaya digunakan dalam konteks penganggaran bukan pelaksanaan, dan markup ditujukan untuk memperhitungkan variasi yang ada dilapangan nantinya.
} 
dalam dokumen anggaran adalah suatu cara memberikan insurance atas rasionalitas harga yang dipilih oleh pengusul.

Penggunaan SBM dan penyertaan SPTJM untuk item-item yang tidak masuk dalam SBM, pada dasarnya, merupakan sinyal bahwa unit cost atas item yang digunakan sebagai bahan dasar untuk melaksanakan kegiatan merupakan harga paling rasional yang tersedia di pasar.

Berangkat dari pemikiran dimaksud, fokus control atas item-item yang tercantum dalam dokumen menjadi tidak relevan untuk didiskusikan secara mendalam. Setidaknya untuk tiga alasan, yaitu: 1.pengusul mempunyai informasi yang lebih untuk memilih unit cost yang sesuai, kecuali reviewer memiliki jumlah informasi yang sama diskusi lanjutan memungkinkan untuk dilakukan; 2.tanggung jawab materiil atas pilihan dimaksud merupakan bagian atas disclaimer dari pengusul ${ }^{4}$; 3.fokus pada item mengurangi fokus yang dicurahkan atas total biaya yang dilakukan untuk pencapaian output maupun outcome.

\subsection{Screening dalam Penganggaran}

Saat signaling digunakan secara luas dalam praktik penganggaran, dilain pihak, teknis screening penganggaran belum banyak dikembangkan. Secara garis besar praktik screening penganggaran berbasis pada peraturan, pengalaman, dan

\footnotetext{
${ }^{4}$ Diskusi pada area ini sangat menarik, terutama jika dikaitkan dengan satuan biaya yang tidak tercantum dalam peraturan Menteri Keuangan. Pertanyaan mendasar dalam diskusi berkisar pada harga apa yang harus dicantumkan dalam dokumen perencanaan? harga spot saat mencantum pada
}

pengetahuan penelaah atas objek penelaahan.

Salah satu arah pengembangan standar biaya mempertimbangkan penggunaan Standar Biaya Keluaran (SBK) sebagai alat screening alokasi, selain fungsi yang selama ini dikenal yakni sebagai alat pemercepat penelaahan. Arah ini dilandaskan pada kenyataan bahwa penyusunan SBK ditujukan bagi output/suboutput yang secara terus menerus ada dalam rencana kerja K/L. Sehingga konsistensi alokasi pada kegiatan dimaksud lebih bisa dihandalkan.

Secara konsep SBK merupakan kumpulan dari unsur-unsur biaya yang terkecil untuk membentuk/memproduksi suatu hasil (output). Pada dasarnya kumpulan biaya ini berupa hasil perkalian antara volume dan unit cost dari unsurunsur pembentuk. Uraian diatas mengambarkan indikasi adanya variasi total cost. Hal ini terjadi sebagai akibat kombinasi dari tiga kondisi, yaitu variasi asumsi volume, variasi asumsi unit cost, dan variasi unsur-unsur pembentuk biaya.

Saat ini, kebijakan SBM pada umumnya menunjuk pada penetapan unit cost, bukan pada volume. Walaupun item yang diatur terbatas, setidaknya variasi atas unit cost lebih terkendali mengingat pengaturan SBM biasa untuk item-ietem yang sering digunakan. Sedangkan kebijakan pengaturan mengenai volume atau unsur pembentuk biaya belum menjadi fokus dalam pengaturan biaya.

dokumen, harga perkiraan dengan berbagai asumsi variasi pada saat pelaksanaan, atau yang lain. Menurut hemat penulis, hal ini merupakan salah satu isu pokok terutama jika terkait dengan pelanggaran hukum pada saat proses pengadaan. 
Penetapan volume dan unsur pembentuk biaya pun dilakukan dalam forum diskusi yang dikenal dengan istilah penelaahan. Dalam diskusi tersebut, reviewer lebih banyak menggunakan professional judgement-nya. Sehingga patut diduga bahwa secara total biaya output akan sangat bervariasi sesuai dengan volume dan unsur pembentuk yang digunakan sebagai asumsi.

Pada dasarnya arah pengembangan SBK tersebut merujuk pada isu ini, yakni mengatasi variasi yang berlebih. Namun demikian, perlu dicatat bahwa SBK tidak berupaya menstandarkan volume dan unsur pembentuk karena hal itu hanya akan menambah rigiditas dalam pelaksanaan anggaran. Melainkan, pengembangan SBK lebih ditujukan untuk mengurangi variasi atas total cost output dimaksud.

Untuk menjadi alat screening penganggaran yang efektif, SBK harus dapat dibandingkan dengan kegiatan yang sejenis, baik dalam maupun antar Kementerian/Lembaga. Guna menambah keadalan atas SBK dibutuhkan pula perbandingan dengan realisasinya ditahun lalu, serta hasil monitoring modifikasi yang dilakukan selama pelaksanaannya. Jika itu dilaksanakan, pada akhirnya konsepsi SBK sebagai alat managemen biaya menjadi lebih mendekati kerangka teoritis.

Urgensi dari pembandingan tersebut adalah untuk menentukan dengan lebih baik biaya suatu output, kegiatan atau bahkan suatu program jika memungkinkan. Dari pembandingan tersebut, informasi yang dihasilkan dapat digunakan sebagai sinyal atas alokasi yang lebih rasional atas suatu output, kegiatan dan program. Selain itu, upaya tersebut mengurangi waktu yang dibutuhkan untuk berdiskusi mengenai biaya.

Saat SBK dapat dibandingkan, baik dengan SBK yang lain atau output sejenis selain SBK, SBK yang bersifat umum dapat ditetapkan setelah berkoordinasi dengan Kementerian/Lembaga. Pembandingan ini memungkinkan rumusan perhitungan biaya yang terangkum dalam sebuah SBK menjadi lebih merepresentasikan kebutuhan sebenarnya.

Bagaimana menentukan SBK yang merepresentasikan kebutuhan sebenarnya? Pertanyaan tersebut merupakan inti dari proses screening. Salah satu cara termudah adalah, misalnya, dengan menggunakan angka rata-rata (atau median/modus) dari SBK sejenis. Rata-rata menunjukkan kecenderungan umum suatu kondisi, sehingga dapat dikatakan bahwa deviasi dari rata-rata memberikan sinyal alokasi yang tidak sesuai dengan kebutuhan.

Langkah yang lebih komplek dapat juga dilakukan dalam proses screening yakni dengan melakukan analisis atas dasar perhitungan biaya suatu output. Sebagai contoh alokasi pelaksanaan audit dimana parameter tambahan atas pelaksanaan pekerjaannya dapat berupa: lama pelaksanaan, jumlah anggota dalam satu tim, dan lokasi pelaksanaan pekerjaan. Jika atas output yang sejenis terdapat variasi yang sangat besar maka perlu dilakukan analisis lebih mendalam atas dasar perhitungan biaya outputnya. Pertanyaan seperti apakah lama pelaksanaannya sama, apakah jumlah anggotanya sama, atau apakah lokasinya berbeda menjadi penting dalam analisis yang lebih mendalam. Hal ini dilakukan untuk menyusun kluster yang sesuai sehingga 
harga rasional dari suatu output dapat ditetapkan.

Proses tersebut dengan sendirinya akan menyingkap informasi yang tersembunyi atas biaya suatu output. Hanya jika proses tersebut dilakukan, selanjutnya koordinasi lebih lanjut dengan Kementerian/Lembaga sebagai bagian dari proses penetapan dapat dilakukan dengan kondisi kedua belah mempunyai informasi yang seimbang atas permasalahan yang sama.

Hasil dari proses screening tersebut nantinya dapat diperoleh suatu pengetahuan umum bahwa untuk melaksanakan audit keuangan di lokasi X, dibutuhkan tim beranggotakan sekian orang dengan lama pengerjaan sekian hari. Pengetahuan tersebut dapat menjadi benchmark atas alokasi output yang sejenis. Sehingga, alokasi dana atas output sejenis akan lebih berdasar.

Output atau SBK hasil proses screening dapat ditetapkan menjadi benchmark dan menjadi SBK umum yang berlaku pada semua Kementerian/lembaga yang melaksanakan output sejenis. Pendekatan penerapan SBK Umum ini pada prinsipnya dapat berupa Fixed-Budget Approach atau Flexible-Budget Approach ${ }^{5}$.

Penetapan benchmark bukan berarti akhir dari upaya untuk mengungkap alokasi yang mendekati kebutuhan. Proses selanjutnya adalah review atas apa yang ditetapkan dengan melihat data pelaksanaan dari benchmark tersebut. Data yang dibutuhkan misalnya, bagaimana benchmark digunakan dalam

${ }^{5}$ Fixed-Budget Approach menginginkan besaran total SBK menjadi besaran yang dijadikan benchmark sehingga penilaian difokuskan pada deviasi dari total SBK dimaksud. Dilain pihak,
RKAKL (pada phase perencanaan), bagaimana pelaksanaan, dan apakah ada revisi terkait dengan rumusan yang ada. Hal ini dilakukan agar benchmark selalu update dengan kebutuhan lapangan.

\subsection{Rasionalitas Metode Statistik Sederhana}

Bagian ini merupakan respon atas kekhawatiran bahwa adanya bias yang mungkin terjadi karena bergantung pada nilai rata-rata untuk menentukan tingkat kebutuhan yang rasional. Kekhawatiran pertama berdasarkan kenyataan bahwa walaupun SBK yang menjadi benchmark akan menurunkan alokasi output yang dialokasikan diatas rata-rata, terdapat efek lainnya yang memicu naiknya alokasi untuk output yang selama berada dibawah rata. Kekhawatiran kedua adalah saat SBK yang sudah ditetapkan dalam pelaksanaannya tidak memadai, mengapa revisi dibebaskan untuk dilampaui sehingga angka rata-rata terangkat naik.

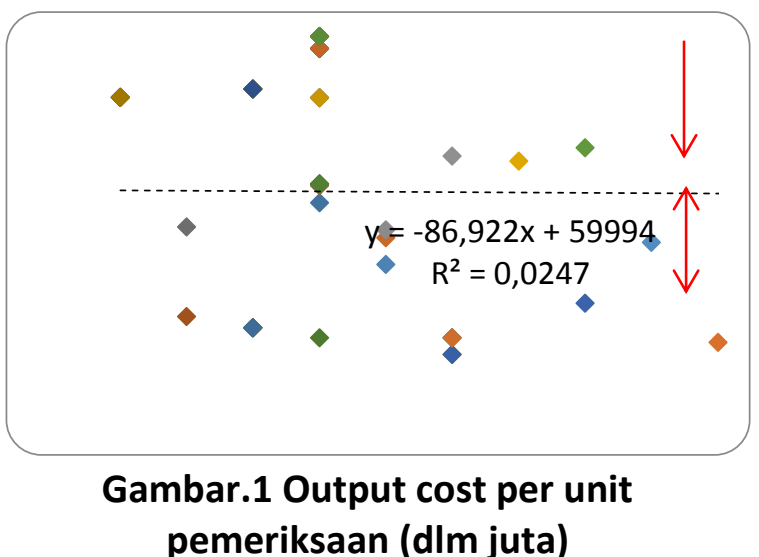

Rasionalitas dari metode ini dapat dilihat pada gambar 1 yang menggambarkan bahwa efek awal dari

Flexible-Budget Approach menginginkan dasar perhitungan biayanya yang menjadi benchmark, yakni, dalam contoh audit, jumlah hari, jumlah anggota tim, serta lokasi. 
kebijakan ini akan menghasilkan pergerakan dari titik origin ke nilai ratarata (digambarkan sebagai garis putusputus). Untuk menjelaskan bahwa kemungkin inefisiensi karena semua output akan bergerak mendekati rata-rata -terutama untuk output dibawah ratarata-- akan dijelaskan dengan Model Dua Output sebagai berikut.

Pertama, perlu diingat bahwa pencantuman output tersebut dalam dokumen akan terdapat dua prilaku yang mungkin terjadi. Untuk Output yang berada di atas rata-rata merupakan keharusan untuk menggunakan angka rata-rata, sedangkan untuk output yang berada di bawah rata-rata merupakan opsi untuk menggunakan angka rata-rata. Selain itu, guna menaikkan unit cost tersebut dibutuhkan total pagu yang memadai. Dengan kata lain, ada konstrain tersendiri untuk meningkatkan unit cost dari output terstandardisasi.

Model dimulai dengan asumsi-asumsi guna menyederhanakan permasalahan. Pertama diasumsikan bahwa semesta dari output terdiri dari dua output, dimana output ini sejenis dan tersebar pada seluruh organisasi. Kedua, pagu dana tetap. Ketiga, pihak penanggung jawab output terlibat dalam kompetisi dalam mendapatkan alokasi. Keempat, jumlah output yang akan dihasilkan adalah sama. Selanjutnya diasumsikan bahwa output cost per unit atas output tersebut adalah sama, dan sesuai dengan angka rata-rata (hasil dari proses screening). Terakhir, setiap penanggung jawab output merupakan budget maximiser.

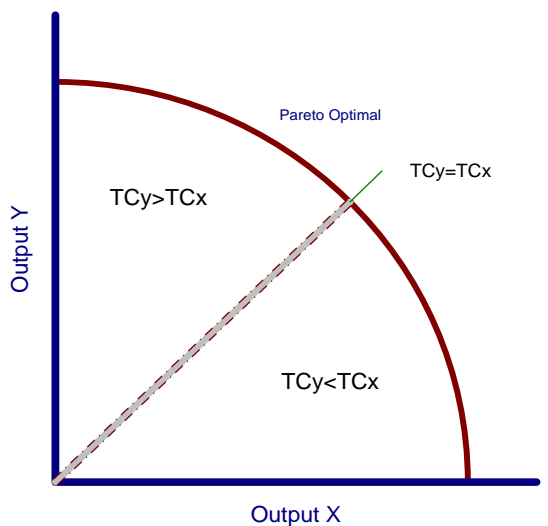

\section{Gambar 2 Model Dua Output}

Pada gambar 2, Sumbu $Y$ merepresentasikan total cost output $Y$ yang dihasilkan dan Sumbu $X$ merepresentasikan total cost output $X$ yang dihasilkan. Saat output mendapatkan alokasi yang sama dan unit cost yang sama, garis putus-putus merepresentasikan titiktitik dimana TCY=TCx. Sesuai dengan asumsi model ini, kondisi ini merupakan posisi awal pada saat dokumen anggaran disahkan. Garis merah melengkung menggambarkan garis optimal dari kombinasi antara Output $X$ dan Output $Y$ dengan pagu tetap. Mengingat pagu tidak berubah maka setiap perubahan alokasi antar output akan pergeseran diantara titik pada garis optimal tersebut.

Seandainya total cost Output $Y$ direvisi menjadi lebih tinggi, maka total cost Output $X$ akan dikurangi untuk memenuhi kebutuhan tersebut (titik menuju ke sumbu $Y$ ). Seandainya penanggung jawab output $Y$ mempunyai intensi yang sangat kuat untuk mengangkat angka rata-rata outputnya, dia akan berusaha keras mengusulkan kenaikan alokasi outputnya dengan harapan angka rata-rata untuk tahun berikutnya akan terangkat. Mengingat Output yang akan dihasilkan tidak boleh dikurangi maka yang bisa 
diupayakan adalah mengurangi output cost per unit untuk output $X$.

Adapun efek yang terjadi apabila penanggung jawab output $X$ setuju untuk revisi dilakukan dapat berupa efek jangka pendek dan jangka panjang. Efek jangka pendeknya adalah berkurangnya alokasi output tahun berjalan. Namun yang terpenting adalah efek jangka panjangnya berupa penurunan angka rata-rata output $X$ untuk tahun berikutnya (hasil dari proses screening).

Dengan demikian, penanggung jawab output $X$ mempunyai insentif untuk menolak revisi dimaksud atau akan menahan revisi hanya pada titik optimal bagi keduanya (tidak terlalu bergeser jauh dari titik origin). Sehingga penanggung jawab output $Y$ setidaknya akan merasionalkan level atas output yang akan dicapai. Signal paling nyata bahwa kebutuhan dana itu memang riel adalah tidak tercapainya output yang direncanakan.

Pada kenyataannya, semesta output tidak terdiri hanya dari dua dimana sebagian besar tidak termonitor. Namun demikian, implikasi dari Model Dua Output adalah output $Y$ bisa jadi "mengatur diri" agar angka rata-rata output tersebut naik sampai suatu kondisi dimana penanggung jawab output lainnya menolak untuk dikurangi. Reviewer tidak harus mengkhawatirkan hal tersebut mengingat secara alamiah proses internal dari organisasi akan mengatur keseimbangannya sendiri.

Kembali pada dua kekhawatiran yang disampaikan pada awal bagian ini, dapat disimpulkan bahwa pada kondisi awal kondisi terangkatnya unit cost output yang dibawah rata-rata merupakan hal lumrah terjadi. Namun demikian, upaya menaikkannya akan berefek pada pengurangan alokasi pada output lainnya sehingga penolakan dalam internal organisasi sangat mungkin terjadi. Terlebih lagi untuk menaikkan angka rata-rata demi kepentingan jangka panjangnya, penanggung jawab output harus bisa mempengaruhi pengguna output sejenis lainnya untuk menaikkan alokasi dana untuk output berkenaan. Hal yang sangat tidak mudah karena itu berarti mempengaruhi organisasi lain diluar kontrolnya.

\subsection{Simulasi Screening Proses}

Sebagai simulasi atas proses screening alokasi, telah diambil data sample dari database Bussiness Intelegent sebanyak 120 output pemeriksaan pada satker Itjen dari 19 Kementerian/Lembaga untuk tahun Anggaran 2013. Output yang dibandingkan adalah output yang terkait dengan kegiatan pemeriksaan, evaluasi, monitoring dan sejenisnya. Data tersebut kemudian diolah dengan microsoft excel 2007 untuk kepentingan analisis lanjutan. Kebutuhan pengolahan data dilakukan untuk mendapatkan nilai regresi (OLS) dan trend, nilai rata-rata, nilai tengah, modus, standar deviasi, nilai minimum, nilai maksimum, serta frekuensi dari data.

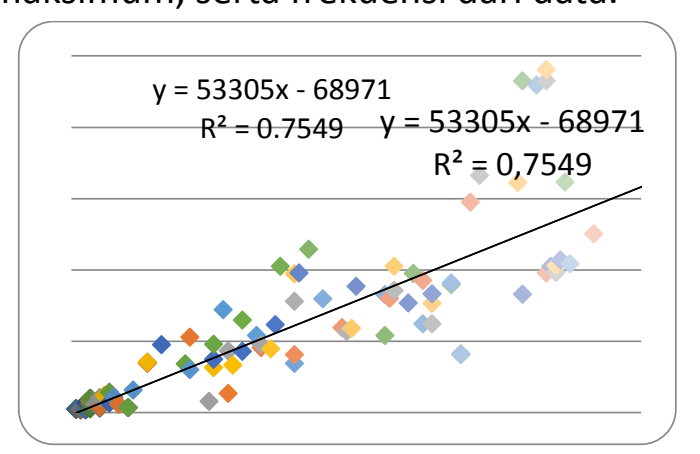

Gambar 3 Total Cost-Total Output output pemeriksaan (dlm juta) 
Sebagaimana tergambar dalam gambar 3 , terlihat hubungan linier antara total biaya dan total output untuk output pemeriksaan. Hal ini mengindikasikan bahwa setiap tambahan output diiringi pula tambahan biaya. Hal ini sangat logis ketika semua/sebagian besar unsur biaya yang membentuk output tersebut adalah biaya variabel.

Langkah lanjutan untuk menggali informasi tentang variasi unit cost atas output diperlihatkan pada gambar 4. Sebagaimana terlihat pada gambar, titik terendah berada dibawah 20 juta per unit sedangkan titik tertinggi berada diatas garis 100 juta per unit. Selisih sebesar 80 juta per pelaksanaan pemeriksaan merupakan variasi yang cukup besar.

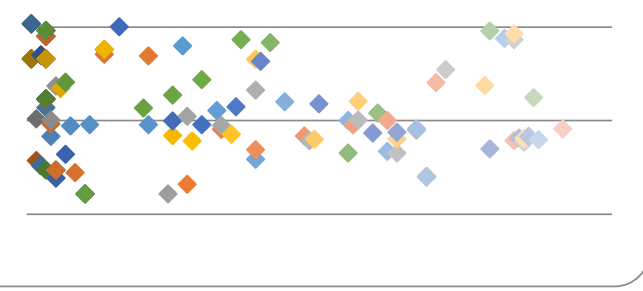

\section{Gambar 4 Output Cost per unit output pemeriksaan (dlm juta)}

\begin{tabular}{|l|l|l|}
\hline Statistik & TC to TO & TC per O \\
\hline Mean & $2,515,362$ & 55,780 \\
\hline Median & $1,631,400$ & 50,200 \\
\hline Modus & $1,631,400$ & 43.757 \\
\hline Max & $14,585,408$ & 101,542 \\
\hline Min & 57,180 & 10,738 \\
\hline Std. Dev & $2,870,663$ & 25,903 \\
\hline
\end{tabular}

\section{Tabel I Statistic Descriptive (dlm juta)}

Jika dikonfirmasi dengan statistik deskriptif pada tabel 1, terlihat bahwa rata-rata output cost per unit sebesar Rp.55,78 juta dengan standar deviasi 土Rp.25,90 juta (atau sebesar $50 \%$ dari rata- rata). selisih antara tertinggi dan terendah sekitar Rp 90,00 juta.

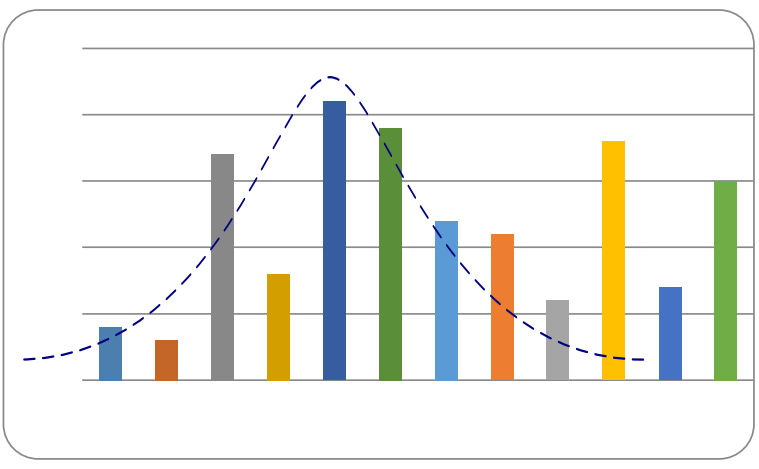

\section{Gambar 5 Frekuensi output cost per unit pada tiap range harga}

Terlihat dalam gambar 5, sebaran terbanyak dari data berada pada nilai antara Rp.40 juta dan Rp.60 juta --nilai yang tidak jauh dari rata-rata. Walaupun terdapat frekuensi yang hampir sama menyaingi pada angka Rp.85 juta dan angka lebih dari Rp.95 juta, angka disekitar rata-rata memiliki frekuensi yang lebih sehingga bisa dikatakan bahwa rata-rata cukup mewakili.

Jika digunakan rata-rata dari data yang ada, SBK untuk output pemeriksaan lintas Kementerian/Lembaga dapat ditetapkan sebesar Rp.55,78 juta. Sebagai catatan, standar deviasi yang tinggi mengindikasikan bahwa data masih terlalu heterogen. Mengingat unsur biaya dominan dalam pelaksanaan pemeriksaan adalah biaya perjalanan, ada kemungkinan heterogenitas data yang tinggi terkait dengan perbedaan lokasi pelaksanaan pemeriksaan dengan lokasi kedudukan auditor. Hal ini bisa diminimalkan dengan membuat kluster-kluster data yang lebih kecil sesuai lokasi tujuan pemeriksaan untuk meningkatkan homogenitas data.

Hasil dari proses berkenaan, dapat menjadi bahan penentuan alokasi untuk 
output dimaksud untuk satu tahun ke depan $(t+1)$. Untuk lebih meningkatkan keunggulan analisis, analis dapat menambahkan analisis trend dari data selama beberapa tahun, misal $\mathrm{t}-1, \mathrm{t}-2, \mathrm{t}-3$,

\section{KESIMPULAN DAN REKOMENDASI}

\section{Pentingnya memperkuat analisa data} Salah satu tantangan terbesar proses penganggaran adalah penentuan besaran alokasi. Tantangan tersebut akan lebih berat lagi jika biaya atas suatu layanan tidak tersedia informasinya di pasar. Oleh karena itu, analisis atas data yang dimiliki menjadi urgen. Rata-rata atas biaya suatu output sejenis mungkin tidak dapat menjadi solusi yang sempurna untuk menilai suatu kebutuhan. Salah satu argumen berkenaan dengan hal tersebut adalah dengan fakta bahwa angka rata-rata akan mengangkat alokasi dana untuk organisasi yang selama ini menganggarkan dana di bawah rata-rata, dan merugikan bagi organisasi yang menganggarkan dana di atas rata-rata. Namun demikian, rata-rata dapat menjadi upaya untuk mencari indikasi kecenderungan umum dalam memproduksi suatu output.

2. Pengelompokan output dan benchmarking

Pengelompokan output dalam jenis tertentu dapat menjadi upaya untuk mencari indikasi kecenderungan umum dalam memproduksi suatu output. Hanya saja memang tidak mudah untuk mengelompokkan output ke dalam jenis yang sama. Selain karena keyakinan tertanam bahwa setiap output adalah unik, belum adanya upaya untuk benarbenar menelaah lebih mendalam atas substansi output-output yang ada menjadi faktor penghambat.

Sejalan dengan itu, kualitas penentuan benchmark bergantung pada kualitas data yang dimiliki. Pada tahap awal titik tolak yang paling krusial adalah menentukan output sejenis sebagaimana disebut diatas. Sebagai contoh apakah pemeriksaan keuangan sejenis dengan pemeriksaan kinerja, apakah pemeriksaan di lokasi A berbeda dengan lokasi B, atau apakah review merupakan keyword yang sama dengan audit. Hanya jika terdapat kesepahaman bersama bahwa contoh-contoh tersebut merupakan output sejenis, pembandingan atas biayanya dapat dilakukan. Jika tidak, diskusi akan diam ditempat.

\section{Mempermudah review baseline}

Dengan asumsi angka MTEF sudah benar, alokasi dana untuk tahun yang direncanakan adalah cost per unit dari output hasil dari proses screening dikalikan dengan kuantitas output yang akan dilaksanakan. Atau dengan kata lain: Alokasi $=\mathrm{PxQ}$, dimana $\mathrm{P}=$ Ouput-Cost per unit dan $Q=a n g k a$ output yang akan dihasilkan. Hal ini juga dapat menjadi solusi atas keakuratan alokasi untuk mengurangi budgetary slack, serta menjadi media untuk meninggalkan fokus detail dibawah output. 


\section{DAFTAR PUSTAKA}

Akerlof, G. 1970. The Market for 'Lemons", Qualitative Uncertainty And The Market Mechanism. Quartely Journal Of Economic 84, 488-500.

Alexander F. Wagner, Nolan H. Miller, Richard J. Zeckhauser, 2006, Screening Budgets, Journal of Economic Behavior \& Organization, Vol.61, Issue 3, 351374.

Anderson, David R., Sweeney, Dennis J., Williams, Thomas A., Statistics for Business and Economics, $11^{\text {th }}$ ed., South-Western Publishing, 2011.

Belkaoui, Ahmed R., Behavioral Management Accounting, Quorom Books, 2002.
Blocher, Edward, Cost Management: A Strategic Emphasis, $4^{\text {th }}$ ed. McGrawHill. 2008.

Leibenstein, Harvey, 1966, Allocative Efficiency vs. "X-Efficiency", American Economic Review, 392-415.

Mikesell, John L., Fiscal Administration: Analysis and Applications for the Public Sector, $8^{\text {th }}$ edition, Wadsworth Publishing, 2011.

Spencer, B., 1982. Asymmetric Infromation and Excessive Budgets in Government Bureaucracies. Journal of Economic Behavior and Organizations 3, 197-224. Stigler, George J., 1961, The Economics of Information, Journal of Political Economy, Volume 69, Issue 3, 213-225. 